\title{
David Burr
}

\section{Textual Authority and Papal Authority in Angelo Clareno's Rule Commentary}

Angelo Clareno led an exciting life ${ }^{1}$. In the 1270 s he was involved in an extended debate over whether the order had departed from Francis' intention. As a result of losing that debate, Angelo and several others were imprisoned for around a decade. After their release, they were sent to Armenia but ran afoul of the Franciscan leaders there and found themselves back in Italy by 1294. Things temporarily looked up for them when they were granted permission by Pope Celestine V to form the Poor Hermits of Pope Celestine, a new order that would observe the Franciscan rule; but Celestine resigned after only four months and his approval of the Poor Hermits disappeared into thin air, leaving Angelo and his colleagues again at the mercy of the Franciscan superiors. Angelo's group decided to flee to Greece, where they spent several years under papal excommunication. When the group finally returned, Angelo went to Avignon, where he lived under the protection of Cardinal Giacomo Colonna. There he tried unsuccessfully to get his Poor Hermits approved.

By 1318 it was clear that he would not win that approval from the current pope, John XXII, and in the process he'd not only been imprisoned for a while but been transferred to the Celestinian order. His patron the cardinal died in that year. Angelo returned to Italy, to Subiaco, where he lived for close to two decades under the protection of a Benedictine abbot. During that time he was guiding a group spread out through a series of small religious communities in central Italy, a group that observed the Franciscan rule but had little or no contact with leaders of the order; a group, in short, not unlike the Poor Hermits for which he had failed to gain papal approval. It was for this group that he wrote a rule commentary sometime in the $1320 \mathrm{~s}^{2}$.

In the history of Franciscan rule commentaries, this one is, to say the least, anomalous. A Celestine living under the protection of a Benedictine abbot yet observing the Franciscan rule is commenting on that rule for the benefit of small

1 For biography see Lydia von Aww, Angelo Clareno et les spirituals italiens (Rome 1979).

2 Expositio super regulam fratrum minorum (hereafter Expositio), edited by Giovanni Boccali (Santa Maria degli Angeli 1995). I will cite my English translation awaiting publication by the Franciscan Institute. 
groups who obey the rule yet have as little as possible to do with the order as an institutional entity. Here we have an explanation of the peculiar emphases within the commentary. To be sure, the work makes a genuine effort to interpret the text of the rule in all its specificity, and in the process addresses many of the same problems dealt with in other commentaries; yet, whatever else it might do, the commentary is an attempt on Angelo's part to justify the life he and his associates have been living by explaining why obedience to the rule takes precedence over obedience to duly-constituted superiors.

In order to make that point convincingly, Angelo must read the rule in a way that neutralizes the substantial emphasis on obedience to superiors contained within it. And that emphasis is indeed substantial. The 1223 rule is laden with passages that insist on obedience. If there is anything on which the two rules and the Testament agree, it is this.

One of the more important steps in Angelo's attempt to neutralize these passages is his emphasis on the fact that the rule was dictated by Christ, and Christ expected it to be observed to the letter. He cites the story of Francis' confrontation with Brother Elias at Fonte Colombo, when he was writing the rule, or, more accurately, when he was serving as amanuensis for the real author, Christ. The ministers had become anxious, because they were afraid the rule would be too difficult, and they had sent Brother Elias to present their position.

When Elias had presented the ministers' complaint,

Blessed Francis turned his face to heaven and said to Christ, "Lord, didn't I say they wouldn't believe me?" Then the voice of Christ was heard in the air replying, "Francis, nothing in the rule is from you. Whatever is there is my doing, and I want the rule to be observed to the letter, to the letter, to the letter, without any gloss ... Whoever does not wish to observe it should get out of the order." Then Blessed Francis turned to the brothers and said to them, "Did you hear? Did you hear? Do you want me to have it said to you again?"3

Later in the commentary Angelo comes to terms with his other important proof text from early Franciscan sources, Francis' Testament, in which Francis says, "I firmly forbid my brothers ... to place glosses on the rule or say, 'This is what it means.' But just as the Lord gave me the power to compose and write both the rule and these words simply and purely, so you must understand them simply and without gloss."4

So far, Angelo has established that the rule was dictated by Christ and thus its authority stems from Christ himself. Of course Christ wanted it ratified by the pope, but to say that much is merely to say that Christ expected the pope to play his part much as he expected Francis to play his. But that does not really settle the problem of what should be done when a friar is convinced that the superiors the

3 Expositio, 6:42-54. This story is in the Collectio Assisiensis, Verba S. P. Francisci, Speculum perfectionis maius ,Legenda maior and Verba fr. Conradi'. Angelo also tells the story in Liber chronicarum sive tribulationum ordinis minorum, edited by Giovanni Boccali (Santa Maria degli Angeli 1999) 1:361-411.

${ }^{4}$ Expositio, 8:50-51. 
rule tells him to obey have ordered him to do something he feels is contrary to the rule Christ has ordered him to obey.

Angelo comes to terms with this problem in his discussion of chapter ten. In the rule of 1223, the definitive rule, it reads as follows:

Brothers who are ministers and servants of other brothers must visit and admonish their brothers, and they should correct them humbly and lovingly, prescribing nothing against their soul or against our rule. Brothers who are subject to authority must remember that they have surrendered their own wills for the sake of God. Thus I strictly order them to obey their ministers in all those things which they have promised the Lord to observe and which are not contrary to the soul and to our rule. And wherever there are brothers who know they cannot observe the rule spiritually, those brothers should and may recur to their ministers. The ministers should receive them lovingly and generously and treat them so intimately that the brothers can speak and act as lords do with their servants. For that is the way it ought to be. The ministers should be servants of all the brothers.

Two things are striking here. First, however strictly Christ seems to be demanding obedience, he qualifies it. The superiors are to order notbing against their soul or against our rule, and the brothers are to obey all orders which are not contrary to the soul and to our rule.

Second, the passage about not being able to observe the rule spiritually is ambiguous to say the least. Does it refer to brothers who realize they themselves are not up to being Franciscans, or is the impediment to be seen as something external to them? The two previous commentaries cited by Angelo, the Commentary of the Four Masters and Olivi's commentary, are both open to the second possibility, and so is Angelo. He says Francis speaks of a case in which brothers

have learned through experience that they cannot observe the rule according to its pure intention and true rectitude in the places where they are, due to bad customs or conditions connected with that particular place, and to diverse circumstances that cannot be avoided yet which induce them to betray the rule and the life they have promised. These circumstances are multifold, involving the place itself, its proprietor, or leaders there who, because they live carnally, do not hesitate to introduce customs contrary to the vow and command subordinates to obey them in these matters ${ }^{5}$.

But is that really what Francis meant in referring to "brothers who know they cannot observe the rule spiritually" ? And what should a brother do if he goes to his superior and that superior refuses to correct the situation? Angelo's answer is to tell a story ${ }^{6}$. He says that according to Brother Leo, when Francis submitted the 1223 rule to Pope Honorius, the passage read as follows:

Wherever there are brothers who know and understand that they cannot observe the rule purely, simply, to the letter and without gloss, they can and should have recourse to their ministers, and the ministers are required by obedience to accede to their requests benignly and liberally. If they are not willing to do so, the

5 Expositio, 10:59-61. Angelo seems to have access only to Olivi's commentary. He is citing the Commentary of the Four Masters as it is quoted by Olivi.

6 Expositio, 10:64-74. The same story is also in Angelo's Liber chronicarum, 1:420-444 and in the Legenda Vetus, 2:2-11, in Opuscules de critique historique, 1 (1902) 92-95. 
brothers have permission and obedience to observe the rule literally, for all the brothers, ministers and subordinates alike, should be subject to the rule.

In other words, the brothers are supposed to obey the rule purely, simply and without gloss, and if their superiors don't want them to do so, they should do it anyway. When Francis submitted the rule to the pope for confirmation, the pope read it and then said he had trouble with that passage. He said the words "could become a cause of ruin to those not fully grounded in love of the virtues and could offer an occasion for division and scandal within the religion". In other words, you cannot simply trust every Franciscan to decide on his own what's involved in obeying the rule purely, simply and without gloss. The pope wanted the passage changed.

Francis said,

I didn't put those words in the rule. Christ did. ... I should not, I cannot change Christ's words.... What stands written in the rule should be ... a matter of obedience.

Then the supreme pontiff said to him, "Brother Francis, I will deal with the matter in such a way that the sense of the words is fully preserved but the letter of the rule is mitigated in such a way that the ministers will know they are obliged to do what Christ wishes and the rule commands, while the brothers will know they are free to observe the rule purely and simply, but those who seek the opportunity to transgress the rule under the pretext of observing it will not be given a reason to do so."

So the pope promised he would rephrase the passage in such a way that the leaders would know they were required to let the brothers observe the rule in its purity, the brothers would know they were free to do so, and yet this freedom would not be abused. We might be tempted to conclude that, if that is what the pope intended, he came well short of succeeding. The difference between the original version as presented by Angelo and the one we now read in the rule is hardly minor. In what Angelo offers as Christ's version, what is at stake is observing the rule "purely, simply and without gloss", which seems a great deal clearer than observing the rule "spiritually". Moreover, in what Angelo sees as Christ's version, friars who feel they cannot observe the rule as the Christ requires are given permission to do two things. First, they can go to their superiors and state their problem. Second, if the superiors refuse to correct the situation, they can go ahead and observe it as they should anyway. The rule as it currently exists gives them permission to do only the former, not the latter.

But from Angelo's perspective the difference is unimportant, because Angelo is not simply providing us with an interesting historical footnote. He is suggesting that we should read the passage even as it now stands as if it still said the very thing the pope thought needed changing. Christ has spoken. He spoke in that original version of the passage.

Lest you doubt that is what Angelo means, listen to what he says next. He says,

This much is clearly demonstrated by all the instructions given to the brothers as a whole in his final Testament, such as that they should not request letters from the Roman church or that they should observe the rule simply and to the letter. It is also proved by the reply given ... to a German brother, a master of theology, who reverently said to Saint Francis, "I firmly propose to observe simply and faithfully, until the end and with the help of Christ's grace, the 
gospel and rule I promised, according to the pure intention that Christ clearly stated through you. But I ask one thing of you. If in my time the brothers decline from the pure observance of the rule as much as you, speaking through the Holy Spirit, predict they will decline, I ask that I be allowed to withdraw from those who are not observing it and, alone or with a few brothers who wish to observe it purely, proceed to observe it perfectly." Hearing this, Blessed Francis rejoiced greatly and, blessing him, said, "Know that what you have asked has been granted by Christ and by me."7

Thus the brother from Germany receives permission from Francis to go off and practice the rule by himself or with a few others if he ever finds it is not being practiced purely within the order. That is, of course, precisely what Angelo and his companions did, over and over.

In reading the 1223 rule this way, Angelo is aided by his view of the 1221 rule, the one we call the regula non bullata. As far as Angelo is concerned, it is very much bullata. He assumes that the 1221 rule is the same as the first Franciscan rule, the one submitted to Innocent III when he and his companions first sought recognition. So the 1221 rule was approved by Innocent III, the 1223 rule was approved by Honorius III, and both were approved by Christ, because Christ was speaking through Francis all the way. Thus, granting that Angelo takes the two rules and the Testament as authoritative, what he is really working with in his commentary is an extended rule consisting of three documents.

That proves important because the 1221 rule encourages the brothers right to show some initiative. In chapter five, instead of saying, as the 1223 rule would say, that a brother is required to obey his superior in all that is not contrary to the rule, it stresses his right not to obey in some circumstances. The wording here is, "If anyone of the ministers commands one of the brothers something contrary to our life or to his soul, he is not bound to obey him because obedience cannot be something through which a fault or sin is committed." Chapter five then goes on to say that all the brothers should pay attention to what their superiors are doing and, "if they see them walking according to the flesh and not according to the Spirit", they should tell them to change their ways. If, after three such attempts at correction, a superior still has not improved, they should report him to the minister general at the next general chapter meeting.

In short, Angelo's extended rule demands obedience to the pope and to the Franciscan superiors, but it also insists that the superiors should not be obeyed if they order something that violates the Franciscan rule. Nor, in fact, should the pope, although Angelo is more cautious about that one. He emphasizes that the pope has authorized the order and its rule (more precisely, its rules). Yet even as he does so he is quietly reducing the value of that authorization by insisting that the pope is merely acknowledging what already has been commanded by Christ himself. He drives that point home in the case of the first rule by encasing the story of its approval in a pair of divine visions. In the first Christ told Francis what he

7 Also in Angelo's Liber chronicarum, 1:220-236, and in Legenda Vetus, 3:1-5 in: Opuscules de critique historique, 1 (1902) 96-97, where it follows directly after the story about the pope's objection and his revision of the passage, just as it does in Expositio. 
should do, and in the second he did the same for Innocent III ${ }^{8}$. When Angelo speaks of Honorius III accepting the 1223 rule he has no papal vision to cite, but he does the next-best thing by combining the story of that acceptance with a reference to how, at the time of its writing on the mountain, Christ himself publicly claimed authorship.

But Angelo argues for the divine authority of the rule, and for the truth of his interpretation of it, in yet another way. He spends a remarkable amount of time arguing that the Franciscan rule is not entirely a thirteenth-century creation. In essence, it represents a return to the grand monastic tradition which began with Christ and his disciples, then was handed on to the apostles, who in turn passed it down to early Greek fathers and the desert fathers.

In the time of Benedict this tradition ran aground, at least in the west. Angelo draws a line between the sort of monasticism he finds in the Franciscan rule and the sort he discovers in what he describes as "the two rules which hold primacy in the Roman church, namely those of Saint Augustine and Saint Benedict"'.

So rather than being a revolutionary step far beyond anything hitherto experienced in monasticism, the Franciscan life is essentially a reform movement. This sense of a single regular life based on the gospe ${ }^{10}$ and appearing in various manifestations throughout history is important to Angelo in several ways. First, it undermines any notion that the Franciscan rule is totally dependent upon papal validation. Christ is insistent on the rule receiving papal approval, but the total effect is to shift major responsibility for the rule from the pope to Christ and from the thirteenth century to the first.

Second, it affords a more complex basis for comparison. The Franciscan order in his time can be measured against not only the rule and primitive Franciscanism, but also early monasticism. Angelo's sense that he is part of a long monastic tradition running back beyond Francis through the desert fathers and Greek monks all the way to Christ gives extra significance to his search for support from previous monastic leaders like Basil and Bernard of Clairvaux, both of whom he cites at length on the need to avoid obeying a superior when he orders something contradictory to Christ's precepts ${ }^{11}$.

Third, it shifts the discussion away from poverty as lack of ownership and toward poverty as restricted use. He never rules the former out, but when he talks about early monasticism the emphasis is clearly on the latter.

8 Expositio, Proemium: 9-12.

9 Expositio, 1:71. See also Expositio, 6:326-328, where he draws the same sort of line.

10 Angelo places limits on emulation of the gospel. He says the Franciscans "promise the evangelical life and rule observed by Christ, his mother and the apostles, insofar as it is offered to us by Christ as a model which is imitable". Expositio, 2:102. See also Expositio, 1:24, "Saint Francis requested as his rule the perfection and life of the gospel of Christ, insofar as the gospel of Christ falls under a vow."

11 Expositio, 10:34-57. Yet he closes by saying that if, after giving the matter rational consideration, the subordinate is not sure whether what has been ordered is a sin, he should obey. 
Fourth, Angelo's sense of walking in the footsteps of the desert fathers helps him to justify a particular sort of religious life that does not follow all that obviously from either the gospels or the Franciscan rule. Among other things, it tips the long-standing tension between eremitical life and worldly engagement in the direction of eremitical life. This eremitical bent must be balanced against Angelo's occasional recognition that the Franciscans are meant to interact with the world through preaching, caring for lepers and the like, but he hardly dwells on that side of the matter, and his sense of the Franciscan mission definitely rules out the sort of migration to the cities and accommodation to urban life he sees as having transformed the order ${ }^{12}$.

This fourth consideration is worth pondering. Angelo is often seen as a major exponent of observing the rule sine glossa. Such is probably the way he saw himself, but only with qualifications. In citing the Fonte Colombo experience and the words of the Testament, he presents the ban against glossing in its most uncompromising form, but on other occasions he sees the problem created by the fact that in writing a commentary he himself is producing a gloss of sorts. In chapter one, when he offers a series of ways in the Franciscan rule differs from the Benedictine and Augustinian rules, number fifteen is that "it differs because they are not to add to the rule or the words of his Testament any glosses which contradict the Lord's right and true intention in giving it to Saint Francis"13. So the sort of glossing Francis prohibits is the kind that distorts the meaning of the text.

The same thought is presented in chapter ten in a passage that speaks directly to the problem of why Angelo should feel able to write a commentary. He says that "when Saint Francis prohibited glosses on his rule he did not mean that arguments, examples, or the authority of the saints illuminating the true meaning of the rule and testament should not be offered, either orally or in writing. Instead, moved by Christ's spirit, he was firmly forbidding glosses that distort the meaning in such a way as to reverse it and introduce relaxations, imperfections or impurities."14

The prohibition of glossing is also qualified in chapter two, but in a slightly different way. He says, "Francis himself declared ... to all brothers present and future ... that it was not his intention, nor was it the pleasure and will of Christ who had mercifully appeared to him and revealed the rule, that the brothers should exposit or gloss the rule in any other way except according to what would strike someone wishing to understand it faithfully as its literal sense."15 So commentaries are acceptable as long as they stick to the literal sense and do not distort the meaning of the text in order to introduce relaxations.

But in reality, Angelo goes well beyond simply avoiding relaxations, and what he gives us can hardly be described as a literal reading. His interpretation of the

12 See Expositio, 1:285, which links Franciscan decline with the abandoning of their "poor, solitary places in the countryside" and relocation in the cities.

13 Expositio, 1:90.

14 Expositio, 10:82-83.

15 Expositio, 2:13. 
rule is uniquely his own. Angelo reads it through the lenses provided him by his understanding of the New Testament; by his assumption that the 1221 rule, the 1223 rule and the Testament are all inspired by Christ and thus they must all say the same thing; by the way he lets the Leo sources shape his view of the early order; by his experience of dissent and persecution within the order; by the years in Greece that enabled him to read the language and translate some of the early Greek fathers, a visible sign of his enduring love affair with early Greek monasticism; by his reading of and admiration for the desert fathers; and by his conversations with a previous generation of Franciscan zealots in central Italy. What Angelo does with the rule is what any decent exegete does. He brings everything he knows and all he's experienced to bear on his text in order to make his own sense of it.

The aim of this paper has been to examine Angelo's view of authority as seen in his rule commentary, and it has done that much; yet the result should not be taken as a thorough exposition of Angelo's thoughts on authority. There are other dimensions to the matter which remain less developed in the commentary than they are elsewhere in Angelo's writings. One of these is the extent to which Angelo, while he grants that one must obey God rather than one's superiors when the two are ordering different things, nonetheless feels that the ecclesiastical hierarchy is divinely established and prelates, whether just or sinful, retain their authority until Christ's second coming ${ }^{16}$. In a letter to Philip of Majorca, he reminds Philip that he follows

Christ, who taught his hearers and disciples by word and action that greedy, illegitimate priests, malevolent, lying scribes, and hypocritical, deceitful pharisees should be heard and honored because of the dignity and honor of their states as well as to preserve peace and unity among the people, lest schism and division should occur before the time established by divine providence, a time set not by human action but by the work of the Holy Spirit ${ }^{17}$.

That model extends to Christ's attitude toward civil authority. Even though it might be exercised by pagans. Christ told his disciples, "Render unto Caesar that which belongs to Caesar" (Mtt. 22:21), and he recognized Pilate's duly-constituted authority, never asking, "Who are you, an idolator, to judge worshippers of the true God?" Angelo makes the same point in connection with idolatrous Israelite kings, observing that the prophets, even though they were persecuted by those same kings, never denied that they were legitimate rulers. When called, they came. When asked for their opinion, they gave $\mathrm{it}^{18}$.

All this ancient history is given an a fortiori application by Angelo. If Christ and the prophets acknowledged the authority of impious Jewish and pagan

16 Opera: I. Epistole, Rome, Istituto Storico Italiano per il Medio Evo (1980) Letter 25, p. 121. Of the many letters relevant here, one might offer letters $3,14,25,29,31$ and 35 as a good introduction to the subject. In fact, much of what follows can be found in letters 25 and 29. On the letters in general, see Gian Luca Potestà, Angelo Clareno, Rome, Istituto Storico italiano per il Medio Evo (1990).

17 Letter 29, p. 151.

18 Letter 25, p. 120. 
leaders, how much more should Angelo and his group respect the authority of Christian offices established by Christ himself? Those occupying such offices, whether saints or sinners, hold the place of Christ and the apostles.

If Christ is the model to be followed, then obedience may entail more than simply following Christ's commands. It may also lead to participation in Christ's suffering, death and resurrection. The letters deal with the concrete, everyday challenges faced by Angelo and his group as they attempt to live the Franciscan vow within a church they see as at times fundamentally hostile to that mission and only too ready to persecute those who remain faithful to the life they have promised. The result is a deepening of Angelo's thought on the matter and the emergence of what we might describe as a sense of obedience as a spiritual path perhaps involving some time on the cross. To follow Christ's way is to honor superiors' commands in all that is not contrary to divine law and one's own salvation, however unpleasant the result may be from the subordinate's perspective. If a prelate orders something that either violates divine law or endangers the subordinate's soul, he should refuse to obey and be ready to take the consequences, even though it may entail receiving a martyr's crown. The important thing is that refusal to obey must not involve anything resembling rebellion or the suggestion that, by issuing an ungodly order, the prelate shows himself to be, in fact, no prelate at all. It is not for inferiors to judge their superiors. Only God and their superiors can rightfully do so. In the case of the Tuscan rebels who, in 1312, took over some houses and then, in the face of force majeure, fled to Sicily, Angelo was sympathetic while they merely suffered persection by their superiors but reacted strongly against them when they ejected their leaders, and he was especially incensed that they had elected their own minister general. Just as the rule could be conceded to Francis only by the pope, Angelo argued, license to elect a minister general could be given only by the pope ${ }^{19}$. Consideration of Angelo's sense of the ecclesiastical hierarchy as established by Christ and enduring until the final judgment brings us a long way toward understanding why, even though he felt the Franciscan rule was dictated by Christ, he also thought it so important to stress that it had been approved by the pope as well.

The letters also offer more insight into Angelo's commitment to seeing the problem in apocalyptic terms, but through a choice of apocalyptic models that give him room for maneuver. As I pointed out in my 2001 book $^{20}$, the apocalyptic source he finds most helpful is not the book of Revelation but the "little apocalypse" of Matthew 24 and its parallels in Mark and Luke. Within the little apocalypse, one of the two passages he relies on most is, "When you see the abomination of desolation foretold by the prophet Daniel standing in the holy place [let the reader take note!], let those who are in Judea flee to the mountains." His letters suggest that his affection for that passage began early and remained strong throughout his life. It provided him with a way of staying faithful to his vow while

19 Letter 25, p. 124.

20 Spiritual Franciscans, 290-295. 
avoiding confrontation. Angelo felt that humility and aggressive witness did not go well together.

Thus, in the letters, we see how complex the problem of obedience really was for Angelo and how a wide variety of factors came together to lead his thought in a single direction. One factor was his sense of a hierarchy established by God and demanding obedience quite apart from the virtues or vices of individual officholders. Another was his sense of spiritual perfection as the imitation of Christ, including Christ's passion, and his emphasis on Christ's self-emptying. Yet another was his identification of Christ's way with Francis' way, a model incarnated in a rule that insisted not only on poverty but on obedience, humility and love. This combination dictated not only that friars must follow their consciences and obey the rule rather than the superior who told them to do otherwise, but bow they should do so.

Still another element in his thinking, however, was a strong element of realism that steered him toward what turned out to be the most prudent path, the one most likely to keep him alive and out of prison. This side of the matter comes through clearly in a letter to Philip of Majorca, who had written to inform him that he planned to write a strong statement on Franciscan poverty and send it to the pope. Angelo, in effect, told him the project was pointless and dangerous. Not only were such matters the province of the ecclesiastical hierarchy and thus not Philip's business, but those in power were a worldly lot and weren't likely to listen to him anyway. The only thing to do was go about one's business and leave the matter to God. "If the supreme pontiff ... defines as heretical that which the church, the doctors and the rules written by the saints deem catholic and the height of perfection, no one judges him but rather he damns and condemns himself." 21

In the letters we are made intensely aware that specific situations demand specific types of action. The ground level, so to speak, of response to the challenge presented by a worldly pope and worldly Franciscan leaders is to keep one's head down and try to remain faithful to the rule wherever one finds oneself, without challenging duly-constituted leaders. That is essentially his advice to Philip of Majorca. "Occupying the place of humility and confession of the truth, we must not speak or write anything ... but should rather leave judgment and examination to Christ, ... attending rather to ourselves, confessing the truth by work and word, justly and humbly going about our business and not presuming beyond our station." 22

That may not work. Angelo goes on to suggest that, if it does not and we find it impossible to observe the rule where we are, then the next-best thing is to change locations. As Matthew 24 suggests, we can flee to the mountains until God in his own good time restores the church to its purity ${ }^{23}$. This can be done without

21 Letter 29, p. 150.

22 Letter 29, p. 150-151.

23 Letter 29, p. 150. 
openly challenging authority, but also without seeking permission or leaving a forwarding address.

Angelo pictures this occurring in different contexts. In the case of the brother from Germany, there is no suggestion that he will leave in order to escape persecution. It is simply a question of going where he can oberve the rule unimpeded. In other passages, however, Angelo explicitly places the need for withdrawal in the context of a persecution visited on Francis' true followers, a persecution predicted by Francis himself. In the rule commentary he says,

Saint Francis preached - as his companions Brother Bernard, Brother Angelo, Brother Masseo, Brother Leo and others testified after his death - that at that time there will be such an agitation and assault of demons and perverse men against those who go about simply and humbly that, abandoned by all, they will be constrained to seek deserted, solitary places, or go among the infidels, or, dispersed in secular clothing, lead a wandering life, or hide among the faithful, or suffer punishment and death accompanied by innumerable calumnies and accusations. Blessed will be he, Francis said, who in such a storm will succeed in finding a faithful companion. For those who persecute them, agitated by evil spirits, will say that killing such pestilent men and eradicating them from the earth is a service to God ${ }^{24}$.

This is hardly the only passage in which Angelo evokes such a scenario. He alludes to it more than once in his letters, including the one to Philip we have just cited. There he suggests that, like the young man in Mark 14:52-53, we should leave our cloak in the hands of our persecutors and flee to solitary places where we can observe the gospel purely ${ }^{25}$.

If that too proves impossible, and we are forced to choose between renouncing the gospel or accepting death, then we must accept death. That final, grim necessity was one Angelo himself never had to face. During his early years as a Franciscan, he endured a long (and probably very unpleasant) imprisonment in Ancona. It was an experience he never had to repeat. Thereafter, his life was invested in a more or less successful effort to stay out of the way ${ }^{26}$. Again and again he attempted to avoid violating his vows as he understood them while also avoiding open defiance of his superiors and its necessary concomitant, punishment. He did so largely by finding situations which would allow him to observe the rule just out of sight or at least just out of reach, whether in Greece, in Avignon under the protection of a powerful cardinal, in Subiaco under the protection of a strong Benedictine abbot, or, finally, in a hermitage in the kingdom of Naples. As we have seen, he thought this behavior was justified by Christ in the gospel, by Francis in his predictions of future tribulation, and by the very text of the Franciscan rule. Thus in his chronicle, when he describes how Bernard of Quintavalle escaped persecution by retreating to a hut on Mount Sefro, Angelo says he "made use of evangelical flight and the founder's license"27. So did Angelo.

24 Expositio, 1:292f. On finding the one faithful companion, see also Letter 25, p. 127 and Letter 35, p. 180.

${ }^{25}$ Letter 29, p. 150.

$26 \mathrm{He}$ was imprisoned again, but not for long.

27 Liber chronicarum, 2:136. 


\section{Summary}

Angelo Clareno's rule commentary emphasized that obedience to the rule took precedence over obedience to Franciscan superiors and even to the pope. It did so primarily by insisting that the rule was dictated by Christ, and Christ expected it to be observed to the letter. In fact, Christ was speaking not only in the rule of 1223 but also in the earlier rule and in the Testament, all of which demand literal observance. Angelo also argued that the Franciscan rule was not a thirteenth-century creation but instead represented a return to the grand monastic tradition which began with Christ and his disciples and then was handed on to the apostles, who in turn passed it down to the early Greek fathers and the desert fathers. This perspective undermined any notion that the Franciscan rule was totally dependent upon papal validation. Christ insisted that the rule must receive papal approval, but the total effect of Angelo's argument was to shift major responsibility for the rule from the pope to Christ and from the thirteenth century to the first. 